\title{
Evaluation of hyper-reflective foci and their association with visual status in diabetic macular edema
}

\author{
Dharmendra Singh, B.P. Guliani, R.K. Duvesh, Gayathri Priya \\ Vardhman Mahavir Medical College and Safdarjung Hospital, New Delhi, India
}

\begin{abstract}
BACKGROUND: This study aimed to know the association of visual status and hyperreflective foci in patients with diabetic macular edema (DME).

MATERIAL AND METHODS: This observational cross-sectional study included patients with diabetes mellitus type 2 (DM2) with DME or non-proliferative diabetic retinopathy (NPDR). Baseline assessment included: ophthalmic examinations such as best-corrected visual acuity (LogMAR), color vision, contrast sensitivity, intraocular pressure (IOP), fundus examination by direct, indirect ophthalmoscopy, slit-lamp biomicroscopy with 90D, and spectraldomain - optical coherence tomography (SD-OCT) [counting of hyperreflective foci (HF) were done manually]. Retina specialists performed counting and classification of HF. The correlation was calculated to establish the association between $\mathrm{HF}$ with visual status. p-value $<0.05$ was considered statistically significant.

RESULTS: In majority of the patients (46.67\%), HF was < 50 followed by $51-100(30.83 \%)$ and $>100(17.50 \%)$. With increasing HF, there was a significantly decreasing trend of best-corrected visual acuity (BCVA) $(0.2$ in no HF to 0.5 in HF $>100, p=0.001$ ) and contrast (1.58 in no HF to 1.35 in HF $>100, p=0.0004)$. HF were found to significantly increase with increasing duration of the disease ( 4 in no HF to 17 in HF $>100, p=0.0001$ ). The lab parameters such as glycated haemoglobin $\left(\mathrm{HbA}_{1 \mathrm{c}}\right)$, serum urea, serum creatinine, triglycerides, very low-density lipoproteins (VLDL), low-density lipoproteins (LDL), and high-density lipoproteins (HDL) showed significant derangement with increasing HF ( $\mathrm{p}<0.05)$.

CONCLUSION: The presence of HF in patients with DME negatively affects BCVA and contrast sensitivity. The severity of HF may increase with the increasing duration of DME and altered glycemic index.
\end{abstract}

KEY WORDS: diabetic macular edema; hyperreflective foci; visual acuity

Ophthalmol J 2021; Vol. 6, 232-240

\section{INTRODUCTION}

Diabetic macular edema (DME), the characteristic feature of diabetic retinopathy (DR), is the most common cause of vision loss among diabetic patients, with an incidence varying from $13.9 \%$ to $25.4 \%[1,2]$.

Significant progress is seen in the microstructural visualization of the integrity of the inner seg-

CORRESPONDING AUTHOR:

Dr Dharmendra Singh, F5 type 3 Safdarjung Staff Quarter, West Kidwai Nagar, New Delhi, 110023, India, tel: 9599644833 ;

e-mail: dr.rajauria4591@gmail.com

This article is available in open access under Creative Common Attribution-Non-Commercial-No Derivatives 4.0 International (CC BY-NC-ND 4.0) license, allowing to download articles and share them with others as long as they credit the authors and the publisher, but without permission to change them in any way or use them commercially 
ment-outer segment (IS/OS) junction, disruption of which is a significant predictor of visual acuity among DME patients [3, 4].

One of the important aspects in the assessment of disruption IS/OS junction is the presence of hyperreflective foci (HF), which is defined as "the presence of small discrete, well-circumscribed, dot-shaped lesion with equal or greater reflectivity than the retinal pigment epithelium (RPE) band on spectral-domain - optical coherence tomography (SD-OCT) [5, 6]. Hyper-reflective material may represent small intra-retinal protein and lipid deposits acting as precursors of hard exudates. The presence of HF could be demonstrated in all types of DME, in diffuse and in cystoid focal or generalized edema. A possible source of these deposits was found in dilated intraretinal vessels, which were identified as micro-aneurysms. HF can also be found among those with age-related macular degeneration (ARMD), retinal venous occlusion (RVO), DR, central serous chorioretinopathy, Stargardt disease, and retinitis pigmentosa [7].

Diabetic macular edema has been seen to be an essential differential for hyperreflective deposits (HD) which may occur due to fluid leakage and lipid-protein deposits. Diabetic macular edema results in blurring and distortion of vision reflected by reduced visual acuity (VA) and coexisting presence of HF $[5,7]$.

We conducted this study to know the association of visual status and HF in patients with DME.

\section{MATERIAL AND METHODS}

An observational cross-sectional study was conducted in the Department of Ophthalmology of a tertiary care hospital (Safdarjung Hospital, New Delhi, India) for 18 months. Consecutive patients with DM over 40 years with DME or non-proliferative diabetic retinopathy (NPDR) were included [8]. Any patient with PDR, ARMD/hereditary macular degeneration, vascular occlusion disease, raised intraocular pressure (IOP), central chorioretinitis, corneal opacities, cataract, vitreous hemorrhage, and epiretinal membrane were excluded. Patients were treated patient with intravitreal anti-VEGF injection or grid photocoagulation.

A sample of 120 eyes of diabetic with macular edema was recruited under the assumption that the correlation( $r$ ) between HF with visual status to be 0.3 , level of significance $(\alpha)$ as $5 \%$, and power $(1-\beta)$ as $90 \%$. The formula used is as follows
$\mathrm{n}=[(\mathrm{Z} \alpha+\mathrm{Z} \beta) / \mathrm{C}]^{2}+3$, where $\mathrm{Z} \alpha=1.96$ at $5 \%$ and $Z \beta=1.282$ at $90 \%$ power, are the standard normal variates.

Patients fulfilling the criteria mentioned above were enrolled in the study after explaining pertinent details of the study and obtaining valid informed consent for the same. Once patients were selected, a baseline assessment was done, including: routine ophthalmic examinations such as best-corrected visual acuity (LogMAR); color Vision; contrast sensitivity; IOP; fundus examination by direct; indirect ophthalmoscopy; slit-lamp biomicroscopy with 90D; and SD-OCT (counting of HF were done manually); and other laboratory investigations such as blood sugar (fasting and $\mathrm{PP}$ ), $\mathrm{HbA}_{1 \mathrm{c}}$, total lipid profile, and kidney function tests (KFT).

Hyperreflective foci was defined as discrete and well-circumscribed particles, having similar or greater reflectivity than the RPE band on SD-OCT, which are about $20-40 \mu \mathrm{m}$ in diameter. Counting of the HRF within a $1.500 \mu \mathrm{m}$ radius centered on the fovea on horizontal raster scan was performed manually [9].

Two experienced retina specialists performed counting of HF. If a disagreement between the two graders was $>20 \%$, the discussion was done to solve the differences. The average of both investigators was used for analysis.[10]

Patients are then divided into four groups for comparison.

- Group 1 - DME with no HF;

- Group 2-DME with HF (1-50);

- Group 3-DME with HF (51-100);

- Group 4 - DME with HF (> 100).

\section{Statistical analysis}

Data were presented, and descriptive values [mean, standard deviation (SD), 95\% confidence interval (CI)], etc., of quantitative variables, were provided. The correlation was calculated to establish the association between HF with visual status. Frequency distribution was given for qualitative variables. $\chi^{2}$ was applied to qualitative variables if needed. $\mathrm{p}$ values for correlation were given, and the significance of the correlation was seen if $p<0.05$. All $\mathrm{p}$ values were provided in the results.

\section{RESULTS}

In the present study, the patient' mean $( \pm S D)$ age was $61.84( \pm 9.2)$ years, and $67.50 \%$ of the patients were males. The left eye and right eye were affected 
in $50.83 \%$ and $49.17 \%$ of patients, respectively. Mean values of best-corrected visial acuity (BCVA), contrast, and IOP was $0.53 \pm 0.23,1.33 \pm 0.18$, and $15.82 \pm 3.7$, respectively. The mean central macular thickness was $428.2 \pm 102.71 \mu \mathrm{m}$. Color vision was deranged in $20.00 \%$ of patients. The median duration of the disease was $15.72 \pm 7$ years. The baseline demographic and clinical characteristics are shown in Table 1.

We found that HF was present in 114 eyes out of 120 eyes. In $46.67 \%$ of patients, HF was $<50$ followed by 51-100 (30.83\%) and >100 (17.50\%). HF was absent in only 6 out of 120 patients (Fig. 1).

Figure 2 shows a representative case of 59 years old female with diabetic macular edema showing hyper-reflective foci (HF), which are seen as highly reflective dots in the retinal layers on optical coherence tomography.

The mean values of serum urea was $41.02 \pm 7.07 \mathrm{mg} / \mathrm{dL}$, serum creatinine was $1.07 \pm 0.25 \mathrm{mg} / \mathrm{dL}$; among glycemic parameters, mean $\mathrm{HbA}_{\mathrm{lc}}(\%)$ was $6.99 \pm 0.88$, mean fasting glucose level was $127.53 \pm 20.53 \mathrm{mg} / \mathrm{dL}$, mean postprandial glucose level was $217.11 \pm 29.4 \mathrm{mg} / \mathrm{dL}$ ); among lipid profile, mean triglycerides was $207.96 \pm 26.24 \mathrm{mg} / \mathrm{dL}$, mean very low-density lipoproteins (VLDL) was $31.22 \pm 6.26 \mathrm{mg} / \mathrm{dL}$, mean low-density lipoproteins (LDL) was $131.18 \pm 11.86 \mathrm{mg} / \mathrm{dL}$, and mean high-density lipoproteins (HDL) was $52.92 \pm 8.24 \mathrm{mg} / \mathrm{dL}$ (Tab. 2).

Hyperreflective foci showed significant association with BCVA, contrast, central macular thickness, and duration. With increasing HF, there was

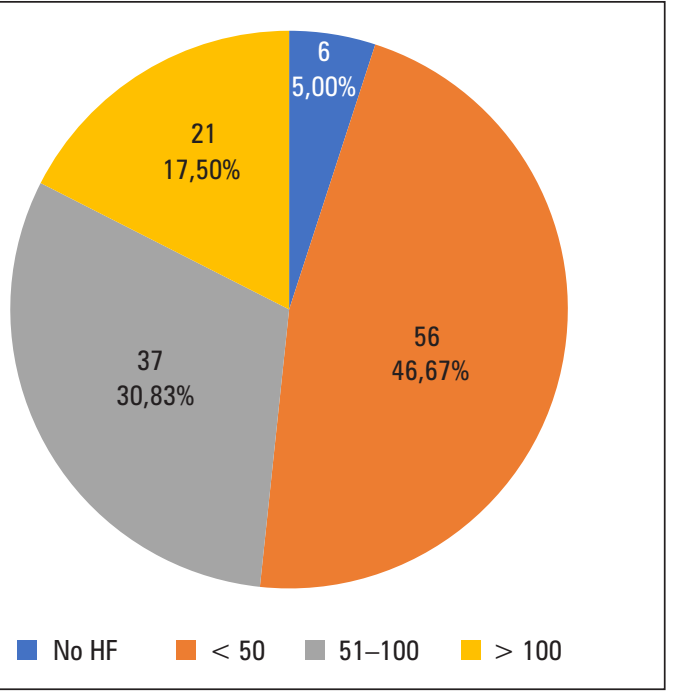

FIGURE 1. Distribution of hyperreflective foci of study subjects

\begin{tabular}{|c|c|c|}
\hline $\begin{array}{l}\text { Socio-demographic } \\
\text { and clinical characteristics }\end{array}$ & Frequency & Percentage \\
\hline \multicolumn{3}{|l|}{ Age [years] } \\
\hline$\leq 50$ & 12 & $10.00 \%$ \\
\hline $51-60$ & 50 & $41.67 \%$ \\
\hline $61-70$ & 34 & $28.33 \%$ \\
\hline$>70$ & 24 & $20.00 \%$ \\
\hline Mean \pm SD & \multicolumn{2}{|c|}{$61.84 \pm 9.2$} \\
\hline Median $\left(25^{\text {th }}-75^{\text {th }}\right.$ percentile $)$ & \multicolumn{2}{|c|}{$60(55.75-68.25)$} \\
\hline Range & \multicolumn{2}{|c|}{$44-84$} \\
\hline \multicolumn{3}{|l|}{ Gender } \\
\hline Female & 39 & $32.50 \%$ \\
\hline Male & 81 & $67.50 \%$ \\
\hline \multicolumn{3}{|l|}{ Eye involved } \\
\hline Left & 61 & $50.83 \%$ \\
\hline Right & 59 & $49.17 \%$ \\
\hline \multicolumn{3}{|l|}{ Best corrected visual acuity } \\
\hline Mean \pm SD & \multicolumn{2}{|c|}{$0.53 \pm 0.23$} \\
\hline Median $\left(25^{\text {th }}-75^{\text {th }}\right.$ percentile $)$ & \multicolumn{2}{|c|}{$0.5(0.3-0.7)$} \\
\hline Range & \multicolumn{2}{|c|}{$0.1-1$} \\
\hline \multicolumn{3}{|l|}{ Color vision } \\
\hline Deranged & 24 & $20.00 \%$ \\
\hline WNL & 96 & $80.00 \%$ \\
\hline \multicolumn{3}{|l|}{ Contrast } \\
\hline Mean \pm SD & \multicolumn{2}{|c|}{$1.33 \pm 0.18$} \\
\hline Median $\left(25^{\text {th }}-75^{\text {th }}\right.$ percentile $)$ & \multicolumn{2}{|c|}{$1.35(1.2-1.5)$} \\
\hline Range & \multicolumn{2}{|c|}{$0.9-1.65$} \\
\hline \multicolumn{3}{|c|}{ Central macular thickness $[\mu \mathrm{m}]$} \\
\hline Mean \pm SD & \multicolumn{2}{|c|}{$428.2 \pm 102.71$} \\
\hline Median $\left(25^{\text {th }}-75^{\text {th }}\right.$ percentile $)$ & \multicolumn{2}{|c|}{$433.5(359.25-500)$} \\
\hline Range & \multicolumn{2}{|c|}{$207-631$} \\
\hline \multicolumn{3}{|l|}{ IOP } \\
\hline Mean \pm SD & \multicolumn{2}{|c|}{$15.82 \pm 3.7$} \\
\hline Median $\left(25^{\text {th }}-75^{\text {th }}\right.$ percentile $)$ & \multicolumn{2}{|c|}{$16(12.75-19)$} \\
\hline Range & \multicolumn{2}{|c|}{$9-23$} \\
\hline \multicolumn{3}{|l|}{ Duration (years) } \\
\hline Mean \pm SD & \multicolumn{2}{|c|}{$15.72 \pm 7$} \\
\hline Median $\left(25^{\text {th }}-75^{\text {th }}\right.$ percentile $)$ & \multicolumn{2}{|c|}{$14(11-20.25)$} \\
\hline Range & \multicolumn{2}{|c|}{$3-34$} \\
\hline
\end{tabular}

SD — standard deviation; WNL — within normal limits; IOP — intraocular pressure

a significantly decreasing trend of BCVA ( 0.2 in no HF to 0.5 in $\mathrm{HF}>100, \mathrm{p}=0.001$ ), a significantly decreasing trend of contrast (1.58 in no HF to 1.35 in $\mathrm{HF}>100, \mathrm{p}=0.0004)$, and a significant increase in the Central macular thickness $(265 \pm 35.18$ in 



FIGURE 2. A. Optical coherence tomography (OCT) showing the macular area; B. The arrow shows macular edema due to diabetes (DME) and hyperreflective foci (HF)

\begin{tabular}{|c|c|c|c|c|c|c|c|}
\hline $\begin{array}{l}\text { Ophthalmological } \\
\text { characteristics }\end{array}$ & $\begin{array}{l}\text { No HF } \\
(n=6)\end{array}$ & $\begin{array}{c}<50 \\
(n=56)\end{array}$ & $\begin{array}{l}51-100 \\
(n=37)\end{array}$ & $\begin{array}{c}>100 \\
(n=21)\end{array}$ & Total & p value & Test performed \\
\hline \multicolumn{8}{|c|}{ Best corrected visual acuity } \\
\hline $\begin{array}{l}\text { Median }\left(25^{\text {th }}-75^{\text {th }}\right. \\
\text { percentile })\end{array}$ & $\begin{array}{c}0.2 \\
(0.125-0.275)\end{array}$ & $0.5(0.3-0.7)$ & $0.6(0.4-0.6)$ & $0.6(0.5-0.8)$ & $0.5(0.3-0.7)$ & 0.001 & $\begin{array}{c}\text { Kruskal Wallis } \\
\text { test; } \\
\chi^{2}=15.483\end{array}$ \\
\hline \multicolumn{8}{|l|}{ Color vision } \\
\hline Deranged & $0(0 \%)$ & $11(19.64 \%)$ & $7(18.92 \%)$ & $6(28.57 \%)$ & $24(20 \%)$ & 0.476 & $\chi^{2}=2.496$ \\
\hline WNL & $6(100 \%)$ & $45(80.36 \%)$ & $30(81.08 \%)$ & $15(71.43 \%)$ & $96(80 \%)$ & & \\
\hline Total & $6(100 \%)$ & $56(100 \%)$ & $37(100 \%)$ & $21(100 \%)$ & $120(100 \%)$ & & \\
\hline \multicolumn{8}{|l|}{ Contrast } \\
\hline $\begin{array}{l}\text { Median }\left(25^{\text {th }}-75^{\text {th }}\right. \\
\text { percentile) }\end{array}$ & $1.58(1.5-1.65)$ & $1.35(1.35-1.5)$ & $1.35(1.2-1.5)$ & $1.35(1.05-1.35)$ & $1.35(1.2-1.5)$ & 0.0004 & $\begin{array}{c}\text { Kruskal Wallis } \\
\text { test; } \\
\chi^{2}=17.984\end{array}$ \\
\hline \multicolumn{8}{|c|}{ Central macular thickness $[\mu \mathrm{m}]$} \\
\hline Mean \pm SD & $265 \pm 35.18$ & $420.43 \pm 103.91$ & $435.78 \pm 89.69$ & $482.19 \pm 83.4$ & $428.2 \pm 102.71$ & $<.0001$ & $\begin{array}{c}\text { ANOVA; } \\
\text { F value }=8.515\end{array}$ \\
\hline \multicolumn{8}{|l|}{ IOP [mm Hg] } \\
\hline $\begin{array}{l}\text { Median }\left(25^{\text {th }}-75^{\text {th }}\right. \\
\text { percentile) }\end{array}$ & $14.5(14-16.5)$ & $16(12-19)$ & $16(12-19)$ & $16(13-18)$ & $16(12.75-19)$ & 0.898 & $\begin{array}{c}\text { Kruskal Wallis } \\
\text { test; } \\
\chi^{2}=0.592\end{array}$ \\
\hline \multicolumn{8}{|l|}{ Duration [years] } \\
\hline $\begin{array}{l}\text { Median }\left(25^{\text {th }}-75^{\text {th }}\right. \\
\text { percentile })\end{array}$ & $4(3.25-7)$ & $14(10-20.25)$ & $14(12-20)$ & $17(15-23)$ & $14(11-20.25)$ & 0.0001 & $\begin{array}{c}\text { Kruskal Wallis } \\
\text { test; } \\
\chi^{2}=20.512\end{array}$ \\
\hline
\end{tabular}

SD — standard deviation; WNL — within normal limits; IOP — intraocular pressure

No HF to $482.19 \pm 83.4$ in $>100$ HF, $p<0.0001$ ). $\mathrm{HF}$ was found to significantly increase with increasing duration of the disease ( 4 in no HF to 17 in $\mathrm{HF}>100, \mathrm{p}=0.0001)(\mathrm{Tab} .3)$.
The lab parameters such as $\mathrm{HbA}_{1}$, serum urea, serum creatinine, triglycerides, VLDL, LDL, and $\mathrm{HDL}$ showed significant association with HF. With increasing HF, there was a significantly increasing trend of 


\begin{tabular}{|c|c|c|c|}
\hline Lab parameters & Mean \pm SD & Median $\left(25^{\text {th }}-75^{\text {th }}\right.$ percentile $)$ & Range \\
\hline Serum urea $[\mathrm{mg} / \mathrm{dL}]$ & $41.02 \pm 7.07$ & $41(36-46)$ & $20-61$ \\
\hline Serum creatinine $[\mathrm{mg} / \mathrm{dL}]$ & $1.07 \pm 0.25$ & $1.1(0.9-1.3)$ & $0.5-1.5$ \\
\hline \multicolumn{4}{|l|}{ Glycemic parameters } \\
\hline $\mathrm{HbA}_{1 \mathrm{c}}(\%)$ & $6.99 \pm 0.88$ & $7(6.1-7.6)$ & $5.6-10.2$ \\
\hline Fasting glucose levels [mg/dL] & $127.53 \pm 20.53$ & $124(114-135)$ & $90-238$ \\
\hline Post prandial glucose level [mg/dL] & $217.11 \pm 29.4$ & $212(196-234)$ & $124-347$ \\
\hline \multicolumn{4}{|l|}{ Lipid profile } \\
\hline Triglycerides [mg/dL] & $207.96 \pm 26.24$ & $208(192-224)$ & $104-262$ \\
\hline VLDL [mg/dL] & $31.22 \pm 6.26$ & $30(26-36)$ & $20-45$ \\
\hline LDL [mg/dL] & $131.18 \pm 11.86$ & $134.5(122.75-140)$ & $106-152$ \\
\hline $\mathrm{HDL}[\mathrm{mg} / \mathrm{dL}]$ & $52.92 \pm 8.24$ & $54(48-58)$ & $34-68$ \\
\hline
\end{tabular}

$\mathrm{HbA}_{1 \mathrm{c}}$ - glycated haemoglobin; VLDL — very low-density lipoproteins; LDL — low-density lipoproteins; $\mathrm{HDL}$ — high-density lipoproteins

$\mathrm{HBA}_{1 \mathrm{c}}$ (5.8 in no $\mathrm{HF}$ to 7.4 in $\left.\mathrm{HF}>100, \mathrm{p}=0.004\right)$, serum urea (34 in no HF to 45 in HF > 100, $\mathrm{p}=0.0001)$, serum creatinine ( 0.7 in no HF to 1 in $\mathrm{HF}>100, \mathrm{p}=0.005$ ), triglycerides (186 in no HF to 231 in $\mathrm{HF}>100, \mathrm{p}<.0001)$, VLDL $(25$ in no HF to 36 in HF $>100, \mathrm{p}<.0001)$, LDL (110 in no HF to 142 in HF $>100, \mathrm{p}<.0001$ ), HDL (68 in no HF to 43 in HF $>100, \mathrm{p}<.0001)$ (Tab. 4).

\section{DISCUSSION}

In the present study, patients with DME were evaluated, where we found that HF was present in 114 eyes out of 120 eyes. HF showed significant association with BCVA, contrast, $\mathrm{HbA}_{1 \mathrm{c}}(\%)$, lipid profile (triglycerides, VLDL, LDL, HDL), renal function test parameters (serum urea and creatinine), duration of disease, and central macular thickness.

In present study, in $46.67 \%$ of patients, HF was < 50 followed by 51-100 (30.83\%) and $>100(17.50 \%)$. HF was absent in only 6 out of 120 patients. Compared to the index study, in the study by Chatziralli et al. [11], the mean $\mathrm{HF}$ at baseline was $12.0 \pm 11.5$ in patients with dexamethasone implant and $10.7 \pm 10.4$ in the ranibizumab arm. Chung et al. [12] reported that mean $\mathrm{HF}$ in $\mathrm{DR}$ and branch retinal vein occlusion (BRVO) was 8.4 and 4.2, respectively. Kim et al. [13] reported that the mean number of HF in the entire retina, inner retina, and outer retina were $11.38 \pm 3.07,5.44 \pm 1.50$, and $5.94 \pm 2.74$, respectively in the early recurrence group and $7.54 \pm 3.60$, $4.08 \pm 1.70$, and $3.46 \pm 2.30$, respectively in late recurrence group.
Diabetic macular edema causes visual impairment among patients with diabetes, mediated by the breakdown of the blood-retinal barrier (BRB) and associated neuroglial dysfunction.

In the index study, compared to the patients with no HF, patients with HF had a significantly worse BCVA (higher logMAR, $\mathrm{p}<0.0001$ ), signifying the negative impact the HF carries on the vision.

Similarly, Uji et al. [14] reported that the presence of HF in the outer retinal layers is significantly associated with poor VA in patients with DME. Visual acuity (logMAR) was significantly higher in patients with HF in outer retinal layers as compared to those without them $(0.463 \pm 0.382$ vs. $0.127 \pm 0.206$, $\mathrm{p}<0.0001)$. Similar findings were seen in some of the previous studies as well $[11,15,16]$.

On the contrary to our findings, Berasategui et al. [17] reported that the number or location of the HF was not an independent influence on VA $(\mathrm{p}=0.513$ and $\mathrm{p}=0.324$, respectively). This was explained by the protective effect of the treatment (generally local or systemic steroids) on photoreceptors and/or the BCVA test's inadequate ability to highlight the functional damage. However, overall it is presumed that HF disrupts the photoreceptors and leads to the reduced vision of an increasing proportion related to the number of HF. Thus it is vital to detect DME early as long-standing DME results in irreversible vision loss.

Despite decreasing the visual acuity, HF had no significant effect on color vision $(\mathrm{p}=0.476)$. Though it has been seen that Macular edema decreases the transmission of light to the photoreceptors and affects color vision, but since all the present 
Table 4. Association of laboratory parameters with hyperreflective foci

\begin{tabular}{|c|c|c|c|c|c|c|c|}
\hline $\begin{array}{l}\text { Ophthalmological } \\
\text { characteristics }\end{array}$ & No $\mathrm{HF}(\mathrm{n}=6)$ & $<50(n=56)$ & $\begin{array}{c}51-100(\mathrm{n}= \\
37)\end{array}$ & $>100(n=21)$ & Total & p value & $\begin{array}{c}\text { Test } \\
\text { performed }\end{array}$ \\
\hline \multicolumn{8}{|l|}{$H_{b A} A_{1 c}(\%)$} \\
\hline $\begin{array}{l}\text { Median } \\
\left(25^{\text {th }}-75^{\text {th }} \text { percentile }\right)\end{array}$ & $5.8(5.65-6.625)$ & $6.85(6-7.525)$ & $7(6.6-7.2)$ & $7.4(6.9-8)$ & $7(6.1-7.6)$ & 0.004 & $\begin{array}{c}\text { Kruskal } \\
\text { Wallis test; } \\
\chi^{2}=13.161\end{array}$ \\
\hline \multicolumn{8}{|c|}{ Fasting glucose levels [mg/dL] } \\
\hline $\begin{array}{l}\text { Median } \\
\left(25^{\text {th }}-75^{\text {th }} \text { percentile }\right)\end{array}$ & $\begin{array}{c}111 \\
(107.25-125.25)\end{array}$ & $124(119-135)$ & $124(111-134)$ & $132(114-141)$ & $124(114-135)$ & 0.14 & $\begin{array}{c}\text { Kruskal } \\
\text { Wallis test; } \\
\chi^{2}=5.476\end{array}$ \\
\hline \multicolumn{8}{|c|}{ Post prandial glucose level [mg/dL] } \\
\hline $\begin{array}{l}\text { Median } \\
\left(25^{\text {th }}-75^{\text {th }} \text { percentile }\right)\end{array}$ & $\begin{array}{c}182 \\
(180.5-226.25)\end{array}$ & $\begin{array}{c}211.5 \\
(195.75-233.25)\end{array}$ & $222(207-230)$ & $217(199-245)$ & $212(196-234)$ & 0.305 & $\begin{array}{c}\text { Kruskal } \\
\text { Wallis test; } \\
\chi^{2}=3.619\end{array}$ \\
\hline \multicolumn{8}{|l|}{ Serum urea $[\mathrm{mg} / \mathrm{dL}]$} \\
\hline $\begin{array}{l}\text { Median } \\
\left(25^{\text {th }}-75^{\text {th }} \text { percentile }\right)\end{array}$ & $34(23.5-34)$ & $38.5(34-45)$ & $45(39-47)$ & $45(40-46)$ & $41(36-46)$ & 0.0001 & $\begin{array}{c}\text { Kruskal } \\
\text { Wallis test; } \\
\chi^{2}=21.814\end{array}$ \\
\hline \multicolumn{8}{|c|}{ Serum creatinine [mg/dL] } \\
\hline $\begin{array}{l}\text { Median } \\
\left(25^{\text {th }}-75^{\text {th }} \text { percentile }\right)\end{array}$ & $0.7(0.55-0.775)$ & $1.2(0.9-1.25)$ & $1.1(0.9-1.3)$ & $1(0.9-1.4)$ & $1.1(0.9-1.3)$ & 0.005 & $\begin{array}{c}\text { Kruskal } \\
\text { Wallis test; } \\
\chi^{2}=12.815\end{array}$ \\
\hline \multicolumn{8}{|l|}{ Triglycerides [mg/dL] } \\
\hline $\begin{array}{l}\text { Median } \\
\left(25^{\text {th }}-75^{\text {th }} \text { percentile }\right)\end{array}$ & $\begin{array}{c}186 \\
(155.25-186)\end{array}$ & $198(190-212)$ & $211(201-222)$ & $231(225-246)$ & $208(192-224)$ & $<.0001$ & $\begin{array}{c}\text { Kruskal } \\
\text { Wallis test; } \\
\chi^{2}=47.243\end{array}$ \\
\hline \multicolumn{8}{|l|}{ VLDL [mg/dL] } \\
\hline $\begin{array}{l}\text { Median } \\
\left(25^{\text {th }}-75^{\text {th }} \text { percentile }\right)\end{array}$ & $25(22-26.5)$ & $28(24.75-30.5)$ & $34(28-38)$ & $36(36-42)$ & $30(26-36)$ & $<.0001$ & $\begin{array}{c}\text { Kruskal } \\
\text { Wallis test; } \\
\chi^{2}=45.939\end{array}$ \\
\hline \multicolumn{8}{|l|}{ LDL [mg/dL] } \\
\hline $\begin{array}{l}\text { Median } \\
\left(25^{\text {th }}-75^{\text {th }} \text { percentile }\right)\end{array}$ & $\begin{array}{c}110 \\
(108.5-113.75)\end{array}$ & $128(120-136)$ & $140(136-140)$ & $142(129-146)$ & $\begin{array}{c}134.5 \\
(122.75-140)\end{array}$ & $<.0001$ & $\begin{array}{c}\text { Kruskal } \\
\text { Wallis test; } \\
\chi^{2}=41.485\end{array}$ \\
\hline \multicolumn{8}{|l|}{ HDL [mg/dL] } \\
\hline $\begin{array}{l}\text { Median } \\
\left(25^{\text {th }}-75^{\text {th }} \text { percentile }\right)\end{array}$ & $68(64.25-68)$ & $56(51.5-59.25)$ & $54(50-56)$ & $43(38-47)$ & $54(48-58)$ & $<.0001$ & $\begin{array}{c}\text { Kruskal } \\
\text { Wallis test; } \\
\chi^{2}=51.316\end{array}$ \\
\hline
\end{tabular}

study participants were of DME and NPDR, it is possible that HF might not have an independent effect on color vision [18].

Diabetic reinopathy is associated with abnormal and decreased contrast sensitivity (CS). Impairment in CS can be found even among diabetic patients who have good VA. Therefore, CS is a significant outcome measure, and it can be an adjunct to standard VA testing for the complete evaluation of visual function in DME patients [19].

In the present study, compared to the patients with no HF, patients with HF had a significantly less contrast; and the contrast showed a signifi- cant decrease with an increasing number of HF $(\mathrm{p}=0.0004)$. Our findings were in line with Echols et al. [20] who found that HF was associated with worse contrast sensitivity $(\mathrm{p}=0.0278)$, low luminance VA ( $\mathrm{p}=0.0010)$, low luminance deficit $(\mathrm{p}=0.0031)$, and mesopic sensitivity.

As explained by Keane et al. [21] there is a close link between contrast sensitivity and both orientation and mobility, which may offer important information related to functional status in patients with DME. Moreover, contrast sensitivity is also helpful for medical retina specialists in clinical settings and a secondary endpoint in clinical trials. 
In line with the odds, we found a significant association of disease duration with HF $(p=0.0001)$. Our findings were in line with Schreur et al. [10] (2019), who found that numbers of HF were associated with longer diabetes duration; however, they included patients with type 1 diabetes in their study. Few studies such as by Chung et al. [12] and Uji et al. [14] found no association of duration of diabetes with a mean number of HF.

In the present study, compared to the patients with no HF, patients with HF had a significantly more central macular thickness $(\mu \mathrm{m})$; and the central macular thickness $(\mu \mathrm{m})$ showed a significant increase with an increasing number of HF ( $p<0.0001)$. The findings of the index study are in accordance with previous studies $[14,17,22]$ who reported that maculae with HF in the outer retinal layers were thicker than those without HF in the outer retinal layers. This can be explained by the fact that HFs are precursors of lipid exudates and, therefore, a sign of hyperpermeability; this can describe the association between a number of foci and macular thickness. The reason behind this association could also be that severe breakdown of the BRB might result in thickening of the retinal parenchyma and extravasation of macromolecules or macrophages.

The biochemical parameters can serve as biomarkers for the severity of DME and HF as they are objective, quantifiable characteristics of a biological process, pathogenic process, or pharmacologic response to therapeutic intervention; and thus, determining their association becomes important for future interventions.

We found significantly deranged glycemic parameters and lipid profile with an increasing number of HF ( $\mathrm{p}<0.05)$, which indicates some role of hyperglycemia and lipid derangement.

Our findings are in accordance with the study by Davoudi et al. [23], who reported that mean $\mathrm{HbA}_{1 \mathrm{c}}$ was significantly higher in patients with HF compared to those without HF (8.5 vs. 7.9, $\mathrm{p}=0.03$ ); Wong et al. [24] found that there was a linear relationship between $\mathrm{HbA}_{1 \mathrm{c}}$ levels and HF count with a strong, positive correlation $(\mathrm{r}=0.952, \mathrm{n}=83$, $\mathrm{p}<0.05)$. Vujosevic et al. [16] mentioned the rise in HF in diabetics compared to normal individuals and diabetics without clinical retinopathy. It is proposed that hyperglycemia can induce the collection of inflammatory cells, which may activate microglial cells and increase HF. Here the severity of inflammation and disease severity may increase the number of HF.
The role of circulating lipids in microvascular complications is still controversial, while the direct correlation was established in macrovascular complications of diabetes.

We observed that compared to the patients with no HF, patients with HF had significantly higher triglycerides, VLDL, and LDL and significantly less HDL $(\mathrm{p}<0.0001)$.

Some of the previous studies support our findings. Davoudi et al. [23] found significant association of total cholesterol in with presence of exudates $(\mathrm{OR}=1.07,95 \% \mathrm{CI}=1.003-1.14, \mathrm{p}=0.04)$. Chung et al. [12] found a significant correlation of HF with triglycerides $(\mathrm{r}=0.523, \mathrm{p}=0.002)$. In a previously mentioned study by Chung et al. [12], higher level of triglycerides was associated with thicker choroi.

Although we determined the relationship of hypercholesterolemia with HF, the causal relationship between dyslipidemia and HF needs to be proven by future prospective studies, based on which clinicians try oral lipid-lowering medications for the treatment of DME.

We also found that serum urea and creatinine significantly increased with the increasing number of HF ( $p<0.0001$ and $p=0.005$, respectively). Our findings were indirectly in line with Saxena et al. [25]. They found a significant positive correlation of serum levels of urea and creatinine with the severity of retinopathy and an increase in grades of disruption of the external limiting membrane (ELM) and inner segment ellipsoid zone (EZ). They suggested that appreciating the role of serum urea and creatinine as surrogate markers for structural alterations in retinal photoreceptors provides a mutual corroboration between $\mathrm{DN}$ and DR. However, no study has directly determined the association of HF with deranged renal function tests.

\section{Limitations of the study}

The limitation was the study's cross-sectional nature, which does not allow us to assess the temporal sequence of these associations. Another limitation of our study is the subjective assessment and counting of HF. Lastly, the location of HF was not assessed.

\section{CONCLUSION}

The presence of HF in patients with DM negatively affects BCVA and contrast sensitivity. The severity of HF may increase with the increasing 
duration of the DME, thus requiring early screening and intervention.

The biomarkers such as $\mathrm{HbA}_{1 \mathrm{c}}(\%)$, lipid profile (triglycerides, VLDL, LDL, HDL), and renal function test parameters (serum urea and creatinine) showed a significant association with HF. Thus their role may be explored in the future to monitor the disease severity and treatment response.

\section{Ethical clearance}

Approval for conducting the study was taken from the Institutional ethical committee. (IEC/VMMC/SJH/Thesis/October/2018-205, dated 31.10.2018)

\section{Authors' contribution}

D.S., B.P.G., R.K.D. - concept and design; D.S., B.P.G. - data collection, literature review; D.S., B.P.G., R.K.G., G.P. - drafting of the manuscript, DS, BPG, GP: data analysis, statistics, and data interpretation; D.S., B.P.G., R.K.G., G.P. - intellectual input, critical revision, and manuscript finalization. All authors provided final approval of the version to be published.

\section{Conflicts of interest}

None declared.

\section{Funding}

None declared.

\section{Acknowledgment}

None declared.

\section{REFERENCES}

1. Moss $\mathrm{S}$. The 14-year incidence of visual loss in a diabetic population, Ophthalmology. 1998; 105(6): 998-1003, doi: 10.1016/s01616420(98)96025-0, indexed in Pubmed: 9627648.

2. Klein R, Klein BE, Moss SE, et al. The Wisconsin Epidemiologic Study of Diabetic Retinopathy. XV. The long-term incidence of macular edema. Ophthalmology. 1995; 102(1): 7-16, doi: 10.1016/s01616420(95)31052-4, indexed in Pubmed: 7831044.

3. Luxmi S, Ritika M, Lubna A, et al. Diabetic macular edema and its association to systemic risk factors in an urban north Indian population. J Clin Ophthalmol. 2018; 02(02), doi: 10.35841/clinicalophthalmology.2.2.86-91.

4. Murakami T, Tsujikawa A, Ohta M, et al. Photoreceptor status after resolved macular edema in branch retinal vein occlusion treated with tissue plasminogen activator. Am J Ophthalmol. 2007; 143(1): 171173, doi: 10.1016/j.ajo.2006.08.030, indexed in Pubmed: 17188062.

5. Lee H, Lee J, Chung H, et al. Baseline spectral domain optical coherence tomographic hyper reflective foci as a predictor of visual outcome and recurrence for central serous chorioretinopathy. Retina. 2016; 36(7): 1372-1380, doi: 10.1097//AE.0000000000000929, indexed in Pubmed: 26702841.

6. Chhablani JK, Kim JS, Cheng L, et al. External limiting membrane as a predictor of visual improvement in diabetic macular edema after pars plana vitrectomy. Graefes Arch Clin Exp Ophthalmol. 2012;
250(10): 1415-1420, doi: 10.1007/s00417-012-1968-x, indexed in Pubmed: 22354371.

7. Bolz M, Schmidt-Erfurth U, Deak G, et al. Optical Coherence Tomographic Hyperreflective Foci. Ophthalmology. 2009; 116(5): 914-920, doi: 10.1016/j.ophtha.2008.12.039, indexed in Pubmed: 19410950 .

8. Standards of Medical Care in Diabetes. Diab Care. 2004; 28(Supplement 1): S4-S36, doi: 10.2337/diacare.28.suppl_1.s4.

9. Schneider CA, Rasband WS, Eliceiri KW. NIH Image to ImageJ: 25 years of image analysis. Nat Methods. 2012; 9(7): 671-675, doi: 10.1038/nmeth.2089, indexed in Pubmed: 22930834.

10. Schreur V, Altay L, van Asten F, et al. Hyperreflective foci on optical coherence tomography associate with treatment outcome for anti-VEGF in patients with diabetic macular edema. PLoS One. 2018; 13(10): e0206482, doi: 10.1371/journal.pone.0206482, indexed in Pubmed: 30379920.

11. Chatziralli IP, Sergentanis TN, Sivaprasad S. Hyperreflective foci as an independent visual outcome predictor in macular edema due to retinal vascular diseases treated with intravitreal dexamethasone or ranibizumab. Retina. 2016; 36(12): 2319-2328, doi: 10.1097/ IAE.0000000000001070, indexed in Pubmed: 27258668.

12. Chung YR, Park SW, Choi SY, et al. Association of statin use and hypertriglyceridemia with diabetic macular edema in patients with type 2 diabetes and diabetic retinopathy. Cardiovasc Diabetol. 2017; 16(1): 4, doi: 10.1186/s12933-016-0486-2, indexed in Pubmed: 28061854.

13. Kim KT, Kim DY, Chae JuB. Association between Hyperreflective Foci on Spectral-Domain Optical Coherence Tomography and Early Recurrence of Diabetic Macular Edema after Intravitreal Dexamethasone Implantation. J Ophthalmol. 2019; 2019: 3459164, doi: 10.1155/2019/3459164, indexed in Pubmed: 31827909.

14. Uji A, Murakami T, Nishijima K, et al. Association between hyperreflective foci in the outer retina, status of photoreceptor layer, and visual acuity in diabetic macular edema. Am J Ophthalmol. 2012; 153(4): 710-7, 717.e1, doi: 10.1016/j.ajo.2011.08.041, indexed in Pubmed: 22137207.

15. Kang JW, Chung H, Chan Kim H. Correlation Of optical coherence tomographic hyperreflective foci with visual outcomes in different patterns of diabetic macular edema. Retina. 2016; 36(9): 1630-1639, doi: 10.1097/IAE.0000000000000995, indexed in Pubmed: 26900741.

16. Vujosevic $S$, Berton M, Bini $S$, et al. Hyperreflective retinal spots and visual function after anti-vascular endothelial growth factor treatment in center-involving diabetic macular edema. Retina. 2016; 36(7): 1298-1308, doi: 10.1097//AE.0000000000000912, indexed in Pubmed: 26689274.

17. Berasategui $B$, Fonollosa $A$, Artaraz $J$, et al. Behavior of hyperreflective foci in non-infectious uveitic macular edema, a 12-month follow-up prospective study. BMC Ophthalmol. 2018; 18(1): 179, doi: 10.1186/ s12886-018-0848-5, indexed in Pubmed: 30029623.

18. Shin YJ, Park KH, Hwang JM, et al. A novel color vision test for detection of diabetic macular edema. Invest Ophthalmol Vis Sci. 2014; 55(1): 25-32, doi: 10.1167/iovs. 13-11698, indexed in Pubmed: 24222302.

19. Nixon DR, Flinn NAp. Evaluation of contrast sensitivity and other visual function outcomes in diabetic macular edema patients following treatment switch to aflibercept from ranibizumab. Clin Ophthalmol. 2018; 12: 191-197, doi: 10.2147/0PTH.S158268, indexed in Pubmed: 29403260.

20. Echols BS, Clark ME, Swain TA, et al. Hyperreflective Foci and Specks Are Associated with Delayed Rod-Mediated Dark Adaptation in Nonneovascular Age-Related Macular Degeneration. Ophthalmol Retina. 2020; 4(11): 1059-1068, doi: 10.1016/j.oret.2020.05.001, indexed in Pubmed: 32389889.

21. Keane PA, Sadda SR. Predicting visual outcomes for macular disease using optical coherence tomography. Saudi J Ophthalmol. 2011; 25(2): 145-158, doi: 10.1016/j.sjopt.2011.01.003, indexed in Pubmed: 23960916.

22. Abri Aghdam K, Pielen A, Framme C, et al. Correlation Between Hyperreflective Foci and Clinical Outcomes in Neovascular Age-Related Macular Degeneration After Switching to Aflibercept. Invest Ophthalmol Vis Sci. 2015; 56(11): 6448-6455, doi: 10.1167/iovs.15-17338, indexed in Pubmed: 26444725. 
23. Davoudi S, Papavasileiou E, Roohipoor R, et al. Optical coherence tomography characteristics of macular edema and hard exudates and their association with lipid serum levels in type 2 diabetes. Retina. 2016; 36(9): 1622-1629, doi: 10.1097/IAE.0000000000001022, indexed in Pubmed: 26991647.

24. Wong BS, Sharanjeet-Kaur S, Ngah NF, et al. The Correlation between Hemoglobin A1c ( $\mathrm{HbA1C}$ ) and Hyperreflective Dots (HRD) in Diabetic
Patients. Int J Environ Res Public Health. 2020; 17(9), doi: 10.3390/ ijerph17093154, indexed in Pubmed: 32369922.

25. Saxena S, Ruia S, Prasad S, et al. Increased serum levels of urea and creatinine are surrogate markers for disruption of retinal photoreceptor external limiting membrane and inner segment ellipsoid zone in type 2 diabetes mellitus. Retina. 2017; 37(2): 344-349, doi: 10.1097/ IAE.0000000000001163, indexed in Pubmed: 28118284. 